\title{
Effect of cancer/testis antigen NY-SAR-35 on the proliferation, migration and invasion of cancer cells
}

\author{
MYUNG-HA SONG ${ }^{1}$, YE-RIN KIM ${ }^{1}$, JAE-HO BAE $^{1}$, CHANG-HUN LEE $^{2}$ and SANG-YULL LEE ${ }^{1}$ \\ Departments of ${ }^{1}$ Biochemistry and ${ }^{2}$ Pathology, School of Medicine, \\ Pusan National University, Yangsan, Gyeongsangnam-do 626-870, Republic of Korea
}

Received January 25, 2016; Accepted November 10, 2016

DOI: $10.3892 / \mathrm{ol} .2016 .5498$

\begin{abstract}
NY-SAR-35 is a cancer/testis (CT) antigen that was identified by serological analysis of recombinant complementary DNA expression libraries. The gene encoding NY-SAR-35 is located on the $\mathrm{X}$ chromosome and is aberrantly expressed in a number of cancer types and germ cells, such as those in the testes, but not in normal tissue. It has been reported that treatment with a demethylating agent induced the expression of NY-SAR-35 in several types of cancer cells. However, the function of NY-SAR-35 in cancer remains undetermined. In present study, the role of NY-SAR-35 in human lung adenocarcinoma (SK-LC-14) and hepatocellular carcinoma (SNU-449) cells was investigated following stable transfection of the NY-SAR-35 gene. NY-SAR-35 was observed to be expressed in the cytoplasm of the cells. In addition, the bromodeoxyuridine incorporation assay and immunofluorescence staining for proliferating cell nuclear antigen and $\mathrm{Ki}-67$ demonstrated that proliferation was increased in cells transfected with NY-SAR-35. In addition, the trypan blue exclusion assay indicated that NY-SAR-35 increased cancer cell viability. Furthermore, NY-SAR-35 increased the migration and invasion of the cells. These results indicate that NY-SAR-35 increases cancer cell viability, proliferation, migration and invasion.
\end{abstract}

\section{Introduction}

Cancer/testis (CT) antigens are a heterogeneous group of $>200$ proteins with an eponymous expression pattern of being restricted to tumor cells of different histological origins, and to germ cells in the testes and placenta (1-4). CT antigens are classified as those that are encoded on the $\mathrm{X}$ chromosome, known as CT-X antigens, and those that are not, which are named non-X CT antigens (5). In total, $>50 \%$ of all the identified

Correspondence to: Professor Sang-Yull Lee, Department of Biochemistry, School of Medicine, Pusan National University, Beomeo-ri, Mulgeum-eup, Yangsan, Gyeongsangnam-do 626-870, Republic of Korea

E-mail: sangyull@pusan.ac.kr

Key words: cancer/testis antigen, NY-SAR-35, hepatocellular carcinoma, lung adenocarcinoma, proliferation, migration
CT antigens to date are CT-X antigens, which are frequently multicopy genes (5). The genes encoding non-X CT antigens, however, are distributed throughout the genome and are typically single-copy genes $(5,6)$. Despite $>200 \mathrm{CT}$ antigens have been categorized, the function of the majority of CT antigens in gametogenesis and carcinogenesis remains unclear $(2,7,8)$.

The CT antigen NY-SAR-35, also referred to as CT antigen 37 or fragile $\mathrm{X}$ mental retardation 1 neighbor, was identified using the serological analysis of recombinant complementary DNA (cDNA) expression libraries (SEREX) method and is encoded by a gene located on the X chromosome (9). NY-SAR-35 is a 255-amino acid multi-pass membrane protein with a predicted molecular mass of 29.2 kDa and a trefoil (P-type) domain (9). The P-type domain is a three-looped clover leaf-shaped domain of 38 amino acids in length, in which the loops are held together by highly conserved disulfide bonds (10-12).

NY-SAR-35 has been identified to be expressed in a number of cancer types, including melanoma, sarcoma, and lung, breast and ovarian cancer (9). Despite the aberrant expression of NY-SAR-35 in a range of malignancies, it is not expressed in certain cancer types, including colon and renal cancer. Analysis of the methylation status of the NY-SAR-35 gene indicated that its expression is regulated by methylation of its promoter region (13).

Hepatocellular carcinoma and lung cancer are the most common tumor types worldwide and the leading causes of cancer-associated mortality in Korea (14-17). A number of germline genes are overexpressed during the development of these malignancies $(5,6,18-23)$, although whether NY-SAR-35 serves a role in their tumorigenesis remains undetermined. The present study hypothesized that NY-SAR-35 may function in oncogenesis. The aim of the current study was to use in vitro cell models lacking the NY-SAR-35 gene to assess the function of NY-SAR-35 in hepatocellular carcinoma and lung cancer. In particular, the current study aimed to determine whether NY-SAR-35 expression affects cell proliferation, migration and invasion in cancer cells.

\section{Materials and methods}

Cell culture. Human hepatocellular carcinoma SNU-449 and lung adenocarcinoma SK-LC-14 cells were obtained from the Korean Cell Line Bank (Cancer Research Institute, Soul National University, Seoul, Korea) and the American Type 
Culture Collection (Manassas, VA, USA), respectively. Cells were maintained in RPMI-1640 medium (Gibco; Thermo Fisher Scientific, Inc., Waltham, MA, USA) supplemented with $10 \%$ fetal bovine serum (FBS; Gibco; Thermo Fisher Scientific, Inc., ), $2 \mathrm{mM}$ L-glutamine, $100 \mathrm{U} / \mathrm{ml}$ penicillin and $100 \mu \mathrm{g} / \mathrm{ml}$ streptomycin. The cells were cultured at $37^{\circ} \mathrm{C}$ in a humidified atmosphere containing $5 \% \mathrm{CO}_{2}$.

Total RNA isolation and reverse transcription-polymerase chain reaction ( $R T-P C R)$. Total RNA was extracted from the cells using the RNeasy Mini kit (Qiagen, Inc., Valencia, CA, USA) according to the manufacturer's protocol. Subsequently, cDNA was synthesized from $1 \mu \mathrm{g}$ total RNA using 5 Units Moloney murine leukemia virus reverse transcriptase (M-MLV) in 5X M-MLV buffer (both Promega Corporation, Madison, WI, USA). The reverse transcriptase and reaction buffer were incubated at $37^{\circ} \mathrm{C}$ for $50 \mathrm{~min}$, prior to RT. RNA and reverse transcriptase were subsequently incubated with 100 pmol random primer (Takara Biotechnology Co., Ltd., Dalian, China) and $1 \mu \mathrm{l}$ mixed dNTPs (10 mM; Solgent Co., Ltd., Seoul, Korea) at $65^{\circ} \mathrm{C}$ for $5 \mathrm{~min}$, and immediately transferred to ice. The NY-SAR-35 primer sequences used were as follows: Forward, 5'-CTTGGTGCGATCAGCCTTAT-3' and reverse, 5'-TTGATGCATGAAAACAGAAC-3'. The GAPDH primer sequences used were as follows: Forward, 5'-GTTTAC ATGTTCCAATATGATTCCAC-3' and reverse, 5'-TCATAT TTGGCAGGTTTTTCTAGAC-3'. PCR amplification was performed using the $2 \mathrm{X}$ TOPsimple ${ }^{\mathrm{TM}}$ DyeMIX-Tenuto kit (Enzynomics, Daejeon, Korea) and the following thermocycling conditions: Denaturation for $5 \mathrm{~min}$ at $94^{\circ} \mathrm{C}$; 35 cycles of $30 \mathrm{sec}$ at $94^{\circ} \mathrm{C}, 30 \mathrm{sec}$ at $55^{\circ} \mathrm{C}$, and $1 \mathrm{~min}$ at $72^{\circ} \mathrm{C}$; and a $10 \mathrm{~min}$ final extension at $72^{\circ} \mathrm{C}$. PCR products were analyzed by $1.2 \%$ agarose gel electrophoresis and visualized using ethidium bromide. The complementary DNA templates were normalized using GAPDH.

Construction of stable cell lines. To generate cells stably expressing NY-SAR-35, the open reading frame of the NY-SAR-35 gene was cloned into the pcDNA3.1/V5-HisA mammalian expression vector (Invitrogen; Thermo Fisher Scientific, Inc.), which has a C-terminal fusion tag (V5 and 6-His epitopes) as well as EcoRI and XhoI restriction sites. Subsequently, cells were seeded into 6 -well plates at a density of $2.5 \times 10^{5}$ cells/well and transfected with $1 \mu \mathrm{g}$ cloned pcDNA3.1/V5-HisA-NY-SAR-35 using Lipofectamine LTX Reagent (Thermo Fisher Scientific, Inc.). Transfected cells were selected by supplementing their culture medium with $1 \mathrm{mg} / \mathrm{ml}$ G418 (Sigma-Aldrich; Merck Millipore, Darmstadt, Germany) and then being maintained in culture medium containing $0.3 \mathrm{mg} / \mathrm{ml} \mathrm{G} 418$. Untransfected cells were used as the control.

Cell viability assay. A total of $5 \times 10^{5}$ cells were seeded into $100-\mathrm{mm}$ culture plates and cultured for 4 days in standard culture medium supplemented with either 1 or $10 \%$ FBS. To test the effect of growth factor withdrawal on the proliferation of NY-SAR-35 transfectants, the cells were trypsinized and the trypan blue solution was added on day 4 , and incubated for $5 \mathrm{~min}$ at room temperature. Subsequently, samples were counted using a hemocytometer and the ratio of viable/dead cells was determined.
Bromodeoxyuridine (BrdU) incorporation assay. Cell proliferation was measured through BrdU incorporation using the Cell Proliferation ELISA BrdU kit (Roche Diagnostics $\mathrm{GmbH}$, Manheim, Germany), according to the manufacturer's protocol. A total of 20,000 cells/well were grown in 96-well plates for 2 days at $37^{\circ} \mathrm{C}$ and labeled with $10 \mu \mathrm{M}$ BrdU for $2 \mathrm{~h}$, prior to fixation and DNA denaturation. Subsequently, anti-BrdU peroxidase-conjugated fragment-antigen binding fragments and substrate were added to the medium, and the optical density at $450 \mathrm{~nm}$ was determined using an ELISA reader (BioTek Instruments, Inc., Winooski, VT, USA) and a reference wavelength of $690 \mathrm{~nm}$.

Immunofluorescence microscopy. Cells were grown at a density of $2 \times 10^{5}$ cells/dish in $35 \mathrm{~mm}$ coverglass-bottom dishes at $37^{\circ} \mathrm{C}$ for $24 \mathrm{~h}$, and were washed with PBS and fixed with $4 \%$ paraformaldehyde. Subsequently, cells were blocked with $3 \%$ FBS in PBS and incubated with anti-proliferating cell nuclear antigen (PCNA; 1:150; BD Biosciences, Franklin Lakes, NJ, USA; cat. no. 555566) or anti-Ki-67 (1:150; BD Biosciences; cat. no. 556003) primary mouse antibodies at $37^{\circ} \mathrm{C}$ for $1 \mathrm{~h}$. Cells were washed three times with PBS and then incubated with fluorescein isothiocyanate-coupled secondary goat antibodies (1:500; BD Biosciences; cat. no. 554001) at $4^{\circ} \mathrm{C}$ for $30 \mathrm{~min}$ in the dark. Cells were visualized and images were captured using a confocal microscope (Olympus Corporation, Tokyo, Japan).

Cell migration and invasion assays. To measure cell migration, transwell chamber assays were performed using a Corning BioCoat Matrigel Invasion Chamber (BD Biosciences, Franklin Lakes, NJ, USA). The lower surface of the filters was coated with $1 \%$ gelatin. Cells were suspended in serum-free RPMI-1640 medium and added to the upper chamber at a density of $5 \times 10^{4}$ cells/insert. Culture medium containing $10 \%$ FBS was added to the lower chamber and the cells were incubated at $37^{\circ} \mathrm{C}$ for $18 \mathrm{~h}$. The number of cells that migrated to the lower side of the upper chamber was counted following staining with crystal violet. To measure cell invasion, the BioCoat Matrigel Invasion chambers (BD Biosciences) were used. The process described above was performed, with the exception that the cells were incubated for $24 \mathrm{~h}$. Inserts were then stained with crystal violet and the number of invading cells was counted. Three fields of cells on the lower side of the chambers were counted, and the migration and invasion of cells were expressed in percentage values compared with those of the mock control cells.

Statistical analysis. Values are presented as the mean \pm standard deviation of three independent experiments. Differences were analyzed using the Student's t-test. The analysis was performed using the SPSS statistical package (version 14.0; SPSS Inc., Chicago, IL, USA). P $<0.05$ were considered to indicate a statistically significant difference.

\section{Results}

Expression and localization of NY-SAR-35 in stably transfected SNU-449 and SK-LC-14 cells. To assess the role of NY-SAR-35 in cancer, NY-SAR-35-positive human hepatocellular carcinoma (SNU449/NY-SAR-35) and lung 


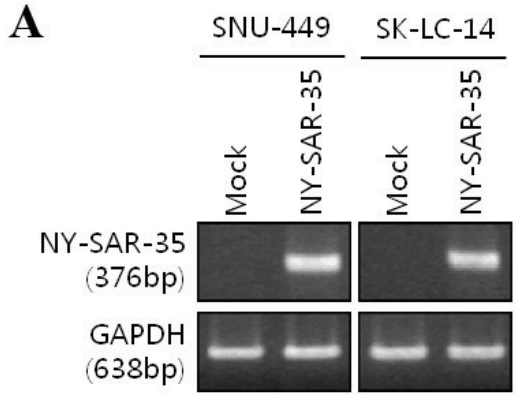

C

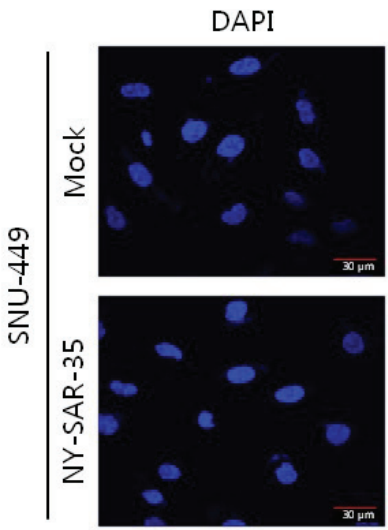

D

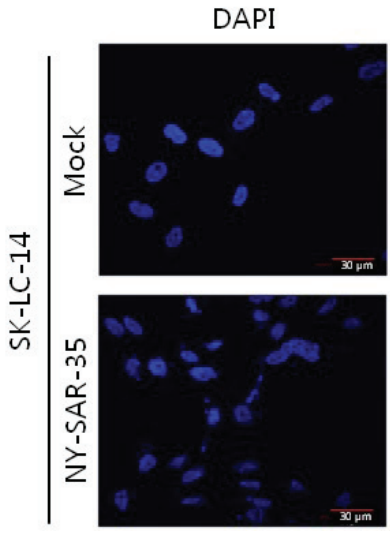

B

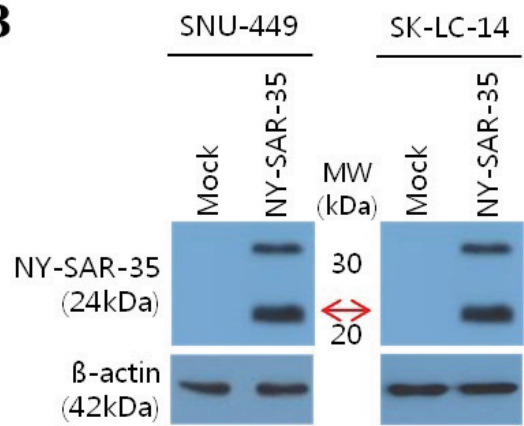

V5-FITC
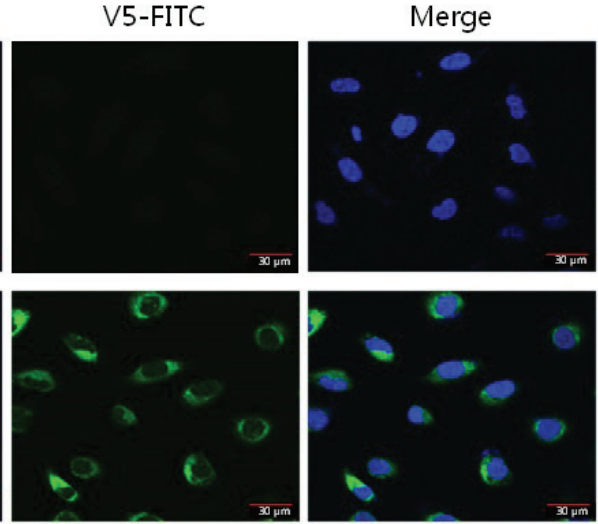

V5-FITC
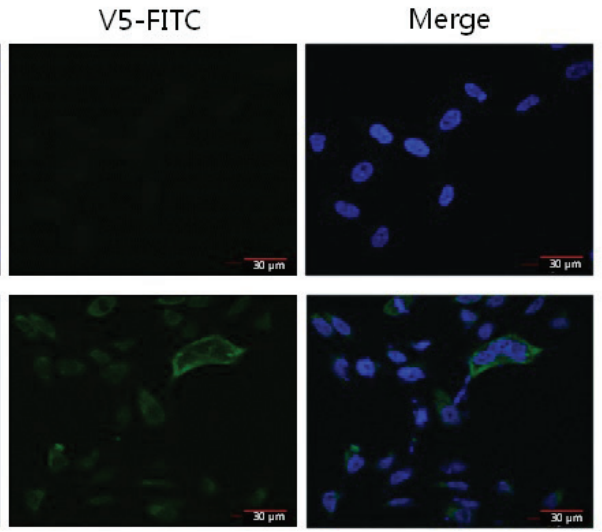

Figure 1. Expression and localization of NY-SAR-35 in stably transfected SNU-449 and SK-LC-14 cells. (A) Reverse transcription-polymerase chain reaction analysis of NY-SAR-35 messenger RNA. (B) Western blot analysis of NY-SAR-35 protein expression. Red arrows indicate the molecular weight of the NY-SAR-35 protein bands (24 kDa). Immunofluorescence of the V5 epitopes antibody (green) and DAPI (blue) in NY-SAR-35 stably transfected (C) SNU-449 and (D) SK-LC14 cells (magnification, x600). FITC, fluorescein isothiocyanate.

adenocarcinoma (SK-LC-14/NY-SAR-35) cell lines, which do not naturally express NY-SAR-35, were established through stable transfection. Expression of NY-SAR-35 messenger RNA and protein in the cells was confirmed using RT-PCR (Fig. 1A) and western blot analysis (Fig. 1B), respectively. The subcellular localization of the NY-SAR-35 was analyzed using immunofluorescence miscopy. This revealed that NY-SAR-35 was located in the cytoplasm of the cells (Fig. 1C and D).

NY-SAR-35 increases SK-LC-14 and SNU-449 cell viability and proliferation. Expression of NY-SAR-35 in SNU-449 cells cultured in medium containing 1 or $10 \%$ FBS significantly increased cell viability by a mean of $1.3-(\mathrm{P}=0.049)$ and 1.9-fold $(\mathrm{P}=0.036)$, respectively, compared with that of mock cells (Fig. 2A). However, no significant difference in viability was noticed between SK-LC-14/NY-SAR-35 and mock cells (Fig. 2B). In addition, BrdU incorporation assays determined that cell proliferation was significantly increased in SNU449/NY-SAR-35 (P=0.002) and SK-LC-14-NY-SAR-35 cells $(\mathrm{P}=0.021)$ compared with that of mock cells (Fig. 2C and D). Furthermore, the effect of NY-SAR-35 expression on SNU449 and SK-LC-14 cell proliferation was analyzed by immunofluorescence staining for PCNA (Fig. 3A) and Ki-67 (Fig. 3B). SNU449/NY-SAR-35 and SK-LC-14/NY-SAR-35 cells had increased PCNA and markedly increased Ki-61 staining compared with those in the mock cells, indicating that NY-SAR-35 stimulates cancer cell proliferation.

NY-SAR-35 increases SK-LC-14 and SNU-449 cell migration and invasion. The migratory and invasive capacities of 
A

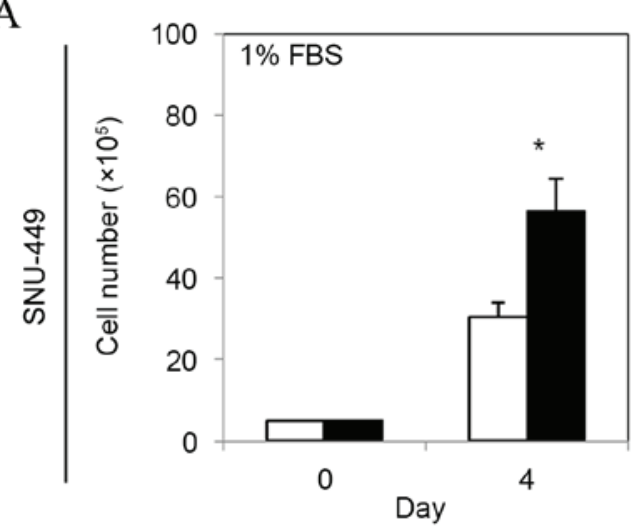

B

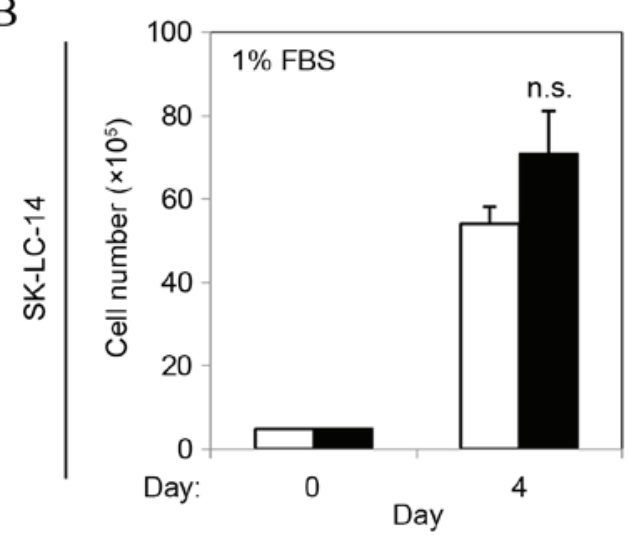

$\mathrm{C}$

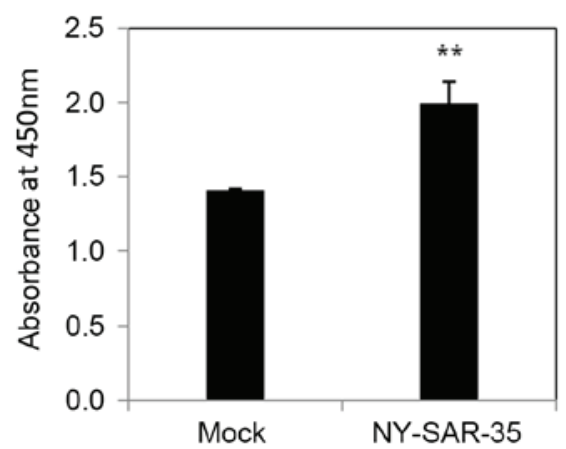

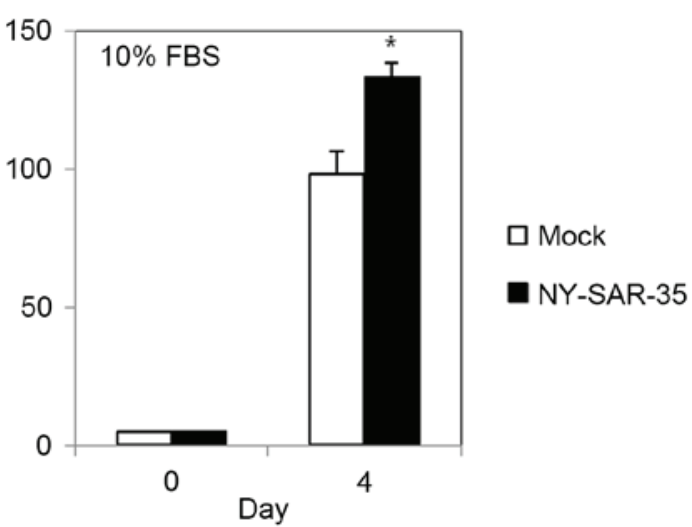

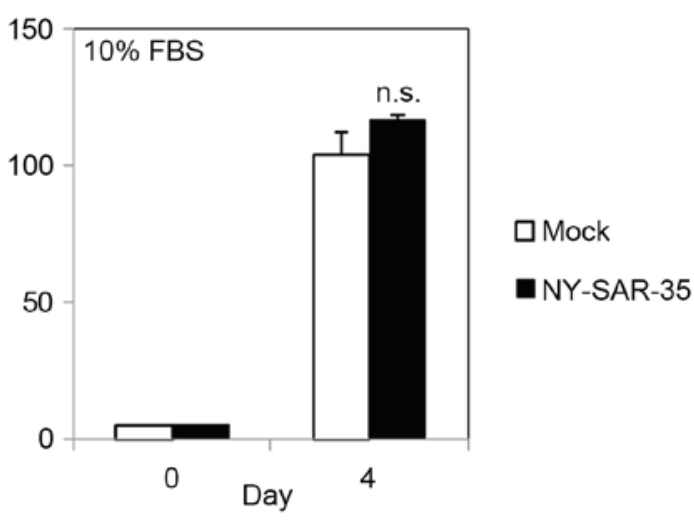

$\mathrm{D}$

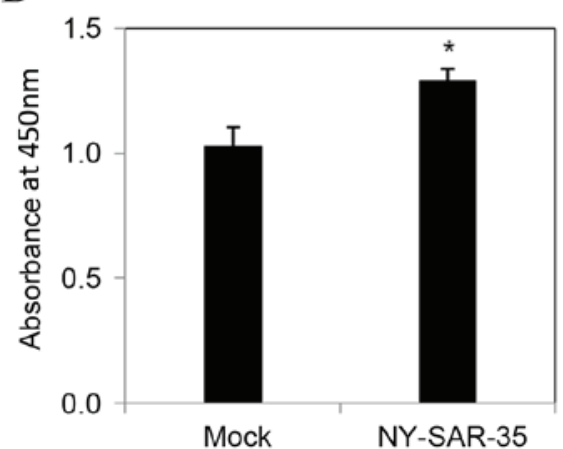

Figure 2. NY-SAR-35 increases the viability and proliferation of SNU449/NY-SAR-35 and SK-LC-14/NY-SAR-35 cells. Trypan blue exclusion assay of the viability of (A) SNU449/NY-SAR-35 and (B) SKLC14/NY-SAR-35 cells cultured in medium containing 1 or 10\% FBS. Results are presented as the mean \pm standard deviation of three independent experiments. BrdU incorporation assay was used to determine the proliferation of (C) SNU449/NY-SAR-35 and (D) SKLC14/NY-SAR-35 cells. ${ }^{*} \mathrm{P}<0.05,{ }^{* * *} \mathrm{P}<0.01$ vs. mock cells. FBS, fetal bovine serum; n.s., no significant difference.

NY-SAR-35-transfected SK-LC-14 and SNU-449 cells were examined using transwell assays. This demonstrated that the migration of SK-LC-14/NY-SAR-35 and SNU449/NY-SAR-35 cells was significantly increased by $2.2-(\mathrm{P}=0.00000137)$ and 6.2-fold ( $\mathrm{P}=0.0000976)$, respectively, compared with that of mock cells (Fig. 4). In addition, cell invasion was increased by 2.5 - $(\mathrm{P}=0.0044)$ and 1.9 -fold $(\mathrm{P}=0.0024)$ in each cell line, compared with that in mock cells (Fig. 4). These results indicate that NY-SAR-35 increases the migration and invasion of cancer cells.

\section{Discussion}

During carcinogenesis, numerous genes that are typically expressed during the embryonic developmental stage are re-expressed in cancer cells, including a number of proto-oncogenes and CT antigens $(2,8,24-27)$. CT antigens are aberrantly expressed in variable proportions of a wide range of different types of tumor; however, not in normal tissues, excluding germ cells. As these cells do not express major histocompatibility class I complexes, cluster of differentiation (CD) $8+\mathrm{T}$ cells are not able to recognize $\mathrm{CT}$ antigens expressed on these cells, suggesting that $\mathrm{CT}$ antigens expressed in tumors are targets for vaccine-based immunotherapy. SEREX-derived CT antigens have been demonstrated to induce CD8+ cytotoxic $\mathrm{T}$ lymphocytes (CTLs), and a positive association was observed between serum positivity for immunoglobulin $\mathrm{G}$ antibody and induction of CD8+ CTLs against several CT antigens, specifically NY-ESO-1 $(2,25)$. Due to these features 
A
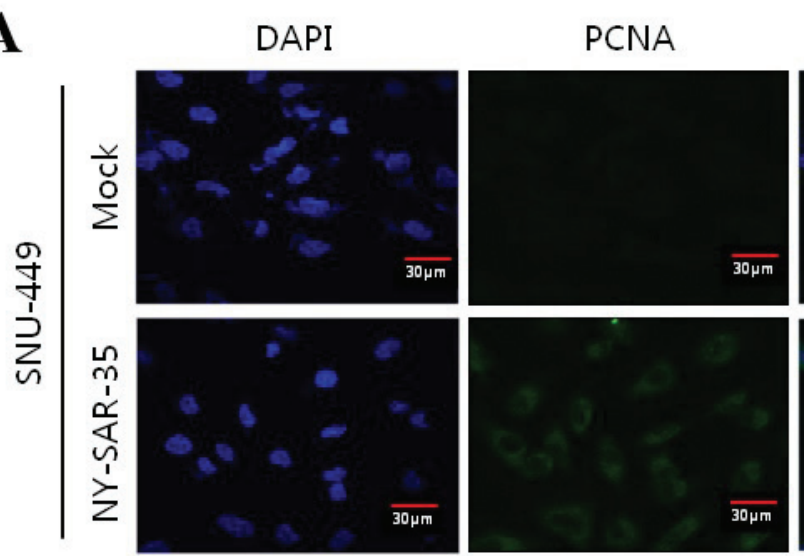

Merge
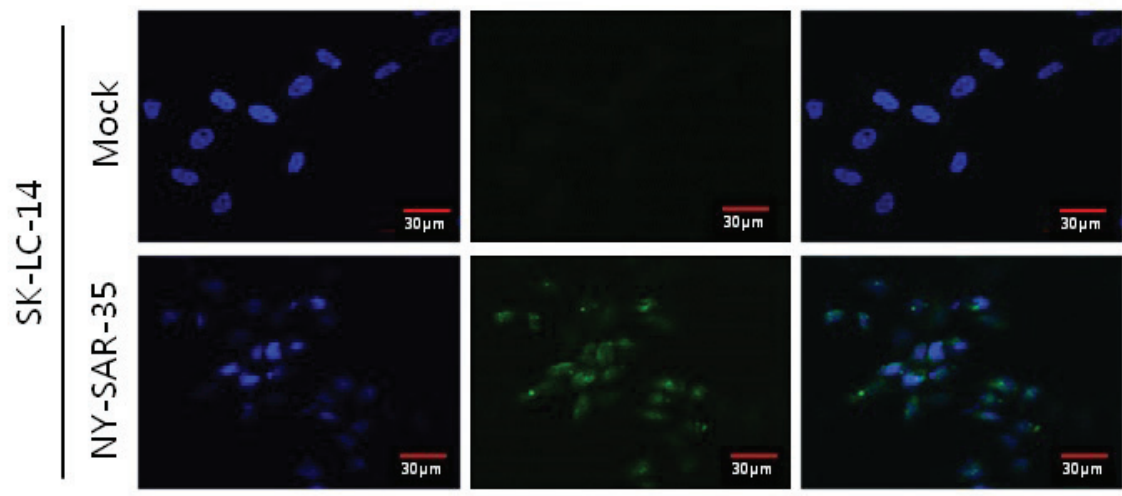

B

DAPI

$\mathrm{Ki}-67$

Merge
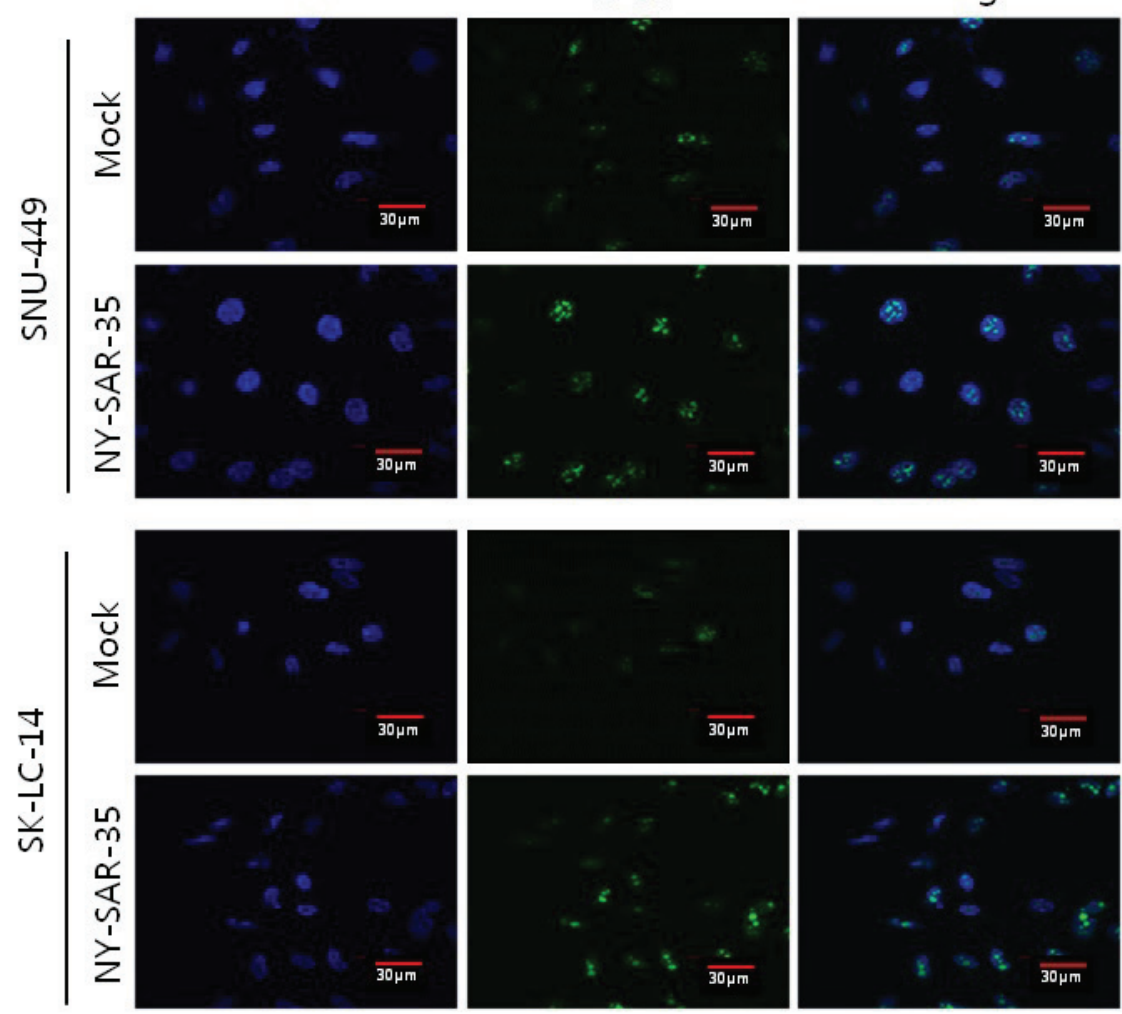

Figure 3. Expression of PCNA and Ki-67 in SNU449/NY-SAR-35 and SK-LC-14/NY-SAR-35 cells. Immunofluorescence microscopy of (A) PCNA and (B) Ki-67 (both green). DAPI (blue) staining was used to visualize the cell nuclei. Magnification, x600. PCNA, proliferating cell nuclear antigen.

of CT antigens, numerous studies have analyzed their potential use in cancer immunotherapy $(1,3)$. NY-SAR-35 was identified as encoding a CT antigen by SEREX (9), and another study suggested that the NY-SAR-35 gene is 

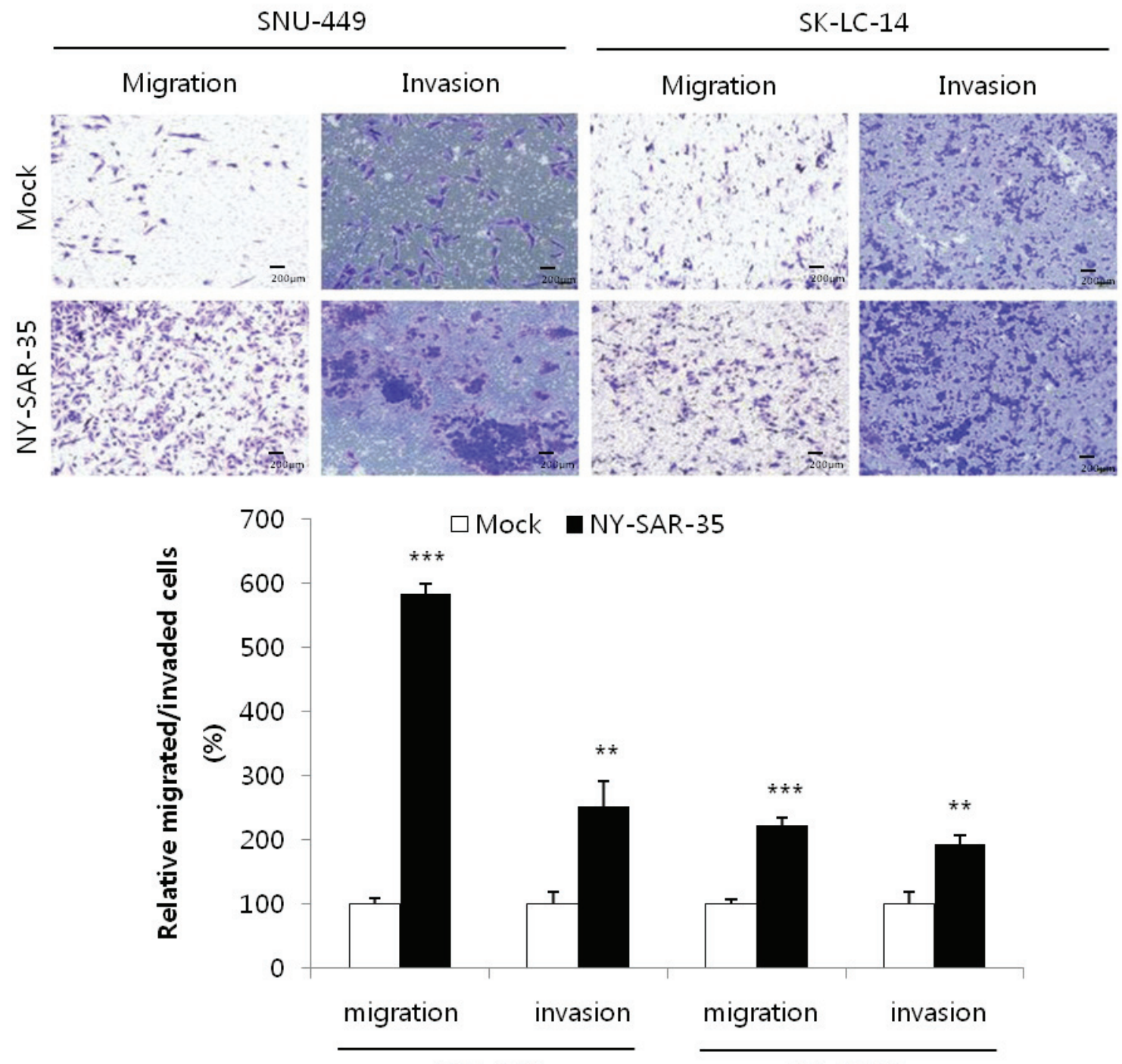

SNU-449

SK-LC-14

Figure 4. NY-SAR-35 increases the migration and invasion of SNU449/NY-SAR-35 and SK-LC-14/NY-SAR-35 cells. Representative images and quantification of transwell migration and invasion assays following crystal violet staining. Magnification, $\mathrm{x} 100 .{ }^{* * *} \mathrm{P}<0.01,{ }^{* * *} \mathrm{P}<0.001$ vs. mock cells.

subject to epigenetic regulation (13). However, the role of NY-SAR-35 in carcinogenesis remains unclear. The results of the present study demonstrated that NY-SAR-35 expression promoted the viability, proliferation, migration and invasion of hepatocellular carcinoma and lung adenocarcinoma cells, suggesting that NY-SAR-35 promotes carcinogenesis.

Immunofluorescence microscopy in the current study identified increased PCNA and markedly increased Ki-67 levels in SK-LC-14/NY-SAR-35 and SNU-449/NY-SAR-35 cells. PCNA is increased in late $\mathrm{G}_{1}$ and $\mathrm{S}$ phases of the cell cycle, and is correlated with the rate of DNA synthesis and cellular proliferation (28). In addition, $\mathrm{Ki}-67$ is associated with cell proliferation and is detected throughout the cell cycle $(29,30)$. The differences observed between the extent of increase of PCNA and Ki-67 levels suggest that these antigens may be differentially affected by NY-SAR-35 expression, which may be due to the fact that they are expressed differently in different cell types (31). Furthermore, NY-SAR-35 expression significantly increased the migration and invasion of hepatocellular and lung carcinoma cells in the present study. This further suggests that NY-SAR-35 promotes cancer progression.

In conclusion, the results of the present study demonstrate that NY-SAR-35 increases cancer cell viability, proliferation, migration and invasion. These results are similar to those observed in human embryonic kidney 293 cells (32). However, the mechanisms underlying the effect of NY-SAR-35 in cancer have not been determined. The results of the current study indicate that this area warrants further study. In addition, further investigation of the effects and mechanisms of NY-SAR-35 may elucidate the functions of other CT antigens, and may provide novel approaches for cancer diagnosis and therapy.

\section{Acknowledgements}

The present study was supported by the Basic Science Research Program of the National Research Foundation of Korea, which is funded by the Ministry of Education of Korea (grant no. NRF-2012R1A1A2041573). 


\section{References}

1. Scanlan MJ, Simpson AJ and Old LJ: The cancer/testis genes: Review, standardization, and commentary. Cancer Immun 4: 1, 2004

2. Fratta E, Coral S, Covre A, Parisi G, Colizzi F, Danielli R, Nicolay HJ, Sigalotti L and Maio M: The biology of cancer testis antigens: Putative function, regulation and therapeutic potential. Mol Oncol 5: 164-182, 2011.

3. Scanlan MJ, Gure AO, Jungbluth AA, Old LJ and Chen YT: Cancer/testis antigens: An expanding family of targets for cancer immunotherapy. Immunol Rev 188: 22-32, 2002.

4. Hofmann O, Caballero OL, Stevenson BJ, Chen YT, Cohen T, Chua R, Maher CA, Panji S, Schaefer U, Kruger A, et al: Genome-wide analysis of cancer/testis gene expression. Proc Natl Acad Sci USA 105: 20422-20427, 2008.

5. Simpson AJ, Caballero OL, Jungbluth A, Chen YT and Old LJ: Cancer/testis antigens, gametogenesis and cancer. Nat Rev Cancer 5: 615-625, 2005.

6. Cheng YH, Wong EW and Cheng CY: Cancer/testis (CT) antigens, carcinogenesis and spermatogenesis. Spermatogenesis 1: 209-220, 2011.

7. Kulkarni P, Shiraishi T, Rajagopalan K, Kim R, Mooney SM and Getzenberg RH: Cancer/testis antigens and urological malignancies. Nat Rev Urol 9: 386-396, 2012.

8. Whitehurst AW: Cause and consequence of cancer/testis antigen activation in cancer. Annu Rev Pharmacol Toxicol 54: 251-272, 2014.

9. Lee SY, Obata Y, Yoshida M, Stockert E, Williamson B, Jungbluth AA, Chen YT, Old LJ and Scanlan MJ: Immunomic analysis of human sarcoma. Proc Natl Acad Sci USA 100 2651-2656, 2003.

10. Thim L: Trefoil peptides: From structure to function. Cell Mol Life Sci 53: 888-903, 1997.

11. Sands BE and Podolsky DK: The trefoil peptide family. Annu Rev Physiol 58: 253-273, 1996.

12. Braun BC, Ringleb J, Waurich R, Viertel D and Jewgenow K: Functional role of feline zona pellucida protein 4 trefoil domain: A sperm receptor or structural component of the domestic cat zona pellucida? Reprod Domest Anim 44 (Suppl 2): S234-S238, 2009.

13. Park JH, Song MH, Lee CH, Lee MK, Park YM, Old L and Lee SY: Expression of the human cancer/testis antigen NY-SAR-35 is activated by $\mathrm{CpG}$ island hypomethylation. Biotechnol Lett 33: 1085-1091, 2011.

14. Davis GL, Dempster J, Meler JD, Orr DW, Walberg MW, Brown B, Berger BD, O'Connor JK and Goldstein RM: Hepatocellular carcinoma: Management of an increasingly common problem. Proc (Bayl Univ Med Cent) 21: 266-280, 2008.

15. Yoon SK and Chun HG: Status of hepatocellular carcinoma in South Korea. Chin Clin Oncol 2: 39, 2013.

16. Bae JM, Lee MS, Shin MH, Kim DH, Li ZM and Ahn YO: Cigarette smoking and risk of lung cancer in Korean men: The Seoul male cancer cohort study. J Korean Med Sci 22: 508-512, 2007.

17. Jung KW, Won YJ, Kong HJ, Oh CM, Seo HG and Lee JS: Cancer statistics in Korea: Incidence, mortality, survival and prevalence in 2010. Cancer Res Treat 45: 1-14, 2013.

18. Chen YT, Hsu M, Lee P, Shin SJ, Mhawech-Fauceglia P, Odunsi K, Altorki NK, Song CJ, Jin BQ, Simpson AJ and Old LJ: Cancer/testis antigen CT45: Analysis of mRNA and protein expression in human cancer. Int J Cancer 124: 2893-2898, 2009.
19. Gure AO, Chua R, Williamson B, Gonen M, Ferrera CA, Gnjatic S, Ritter G, Simpson AJ, Chen YT, Old LJ and Altorki NK: Cancer-testis genes are coordinately expressed and are markers of poor outcome in non-small cell lung cancer. Clin Cancer Res 11: 8055-8062, 2005.

20. Peng JR, Chen HS, Mou DC, Cao J, Cong X, Qin LL, Wei L, Leng XS, Wang Y and Chen WF: Expression of cancer/testis (CT) antigens in Chinese hepatocellular carcinoma and its correlation with clinical parameters. Cancer Lett 219: 223-232, 2005.

21. Nakagawa K, Noguchi Y, Uenaka A, Sato S, Okumura H, Tanaka M, Shimono M, Ali Eldib AM, Ono T, Ohara N, et al: XAGE-1 expression in non-small cell lung cancer and antibody response in patients. Clin Cancer Res 11: 5496-5503, 2005.

22. Kurashige T, Noguchi Y, Saika T, Ono T, Nagata Y, Jungbluth A, Ritter G, Chen YT, Stockert E, Tsushima T, et al: Ny-ESO-1 expression and immunogenicity associated with transitional cell carcinoma: Correlation with tumor grade. Cancer Res 61: 4671-4674, 2001

23. Scanlan MJ, Altorki NK, Gure AO, Williamson B, Jungbluth A, Chen YT and Old LJ: Expression of cancer-testis antigens in lung cancer: Definition of bromodomain testis-specific gene (BRDT) as a new CT gene, CT9. Cancer Lett 150: 155-164, 2000.

24. Ayyoub M, Taub RN, Keohan ML, Hesdorffer M, Metthez G, Memeo L, Mansukhani M, Hibshoosh H, Hesdorffer CS and Valmori D: The frequent expression of cancer/testis antigens provides opportunities for immunotherapeutic targeting of sarcoma. Cancer Immun 4: 7, 2004.

25. Dobrynin P, Matyunina E, Malov SV and Kozlov AP: The novelty of human cancer/testis antigen encoding genes in evolution. Int J Genomics 2013: 105108, 2013.

26. Pandey A, Kurup A, Shrivastava A, Radhi S, Nguyen DD, Arentz C, D'Chuna N, Hardwick F, D'Souza MJ, Jenkins M, et al: Cancer testes antigens in breast cancer: Biological role, regulation, and therapeutic applicability. Int Rev Immunol 31: 302-320, 2012.

27. Shiraishi T, Terada N, Zeng Y, Suyama T, Luo J, Trock B, Kulkarni P and Getzenberg RH: Cancer/testis antigens as potential predictors of biochemical recurrence of prostate cancer following radical prostatectomy. J Transl Med 9: 153, 2011.

28. Kelman Z: PCNA: Structure, functions and interactions. Oncogene 14: 629-640, 1997.

29. Gerdes J, Schwab U, Lemke H and Stein H: Production of a mouse monoclonal antibody reactive with a human nuclear antigen associated with cell proliferation. Int J Cancer 31: 13-20, 1983.

30. Ihmann T, Liu J, Schwabe W, Häusler P, Behnke D, Bruch HP, Broll R, Windhovel U and Duchrow M: High-level mRNA quantification of proliferation marker pKi-67 is correlated with favorable prognosis in colorectal carcinoma. J Cancer Res Clin Oncol 130: 749-756, 2004.

31. Bologna-Molina R, Mosqueda-Taylor A, Molina-Frechero N, Mori-Estevez AD and Sánchez-Acuña G: Comparison of the value of PCNA and Ki-67 as markers of cell proliferation in ameloblastic tumors. Med Oral Patol Oral Cir Bucal 1: e174-e179, 2013.

32. Song MH, Kim YR, Lee JW, Lee CH and Lee SY: Cancer/testis antigen NY-SAR-35 enhances cell proliferation, migration and invasion. Int J Oncol 48: 569-576, 2016. 